\title{
"Linajes de embustes": cargas de centurias y tiempos universales en el mundo maya colonial
}

"Lineages of lies": loads of centuries and universal times in the Maya colonial world

"Lignages de tromperie ": charges des siècles et temps universels dans les

discours mayas coloniaux

\section{Mario Humberto Ruz}

\section{OpenEdition}

\section{Journals}

Edición electrónica

URL: http://journals.openedition.org/jsa/15379

DOI: $10.4000 /$ jsa. 15379

ISSN: 1957-7842

Editor

Société des américanistes

Referencia electrónica

Mario Humberto Ruz, " "Linajes de embustes": cargas de centurias y tiempos universales en el mundo maya colonial », Journal de la société des américanistes [En línea], Maya times | 2017, Publicado el 31 diciembre 2017, consultado el 14 noviembre 2019. URL : http://journals.openedition.org/jsa/15379 ; DOI : 10.4000/jsa. 15379 


\title{
"Linajes de embustes": cargas de centurias y tiempos universales en el mundo maya colonial
}

\author{
Mario Humberto RuZ*
}

El encuentro con Occidente y la imposición de nuevos parámetros cronológicos y cronométricos, obligó a la cultura maya, desde siempre fascinada por la concepción y el registro del tiempo, a adecuar sus parámetros a la visión de sus dominadores españoles. Entre las diversas estrategias que eligió para lograrlo se cuentan la re-significación de sus antiguas medidas de mensura y la inserción de sus propios acontecimientos y procesos históricos en la visión providencialista y pretendidamente universal que caracterizaba a la concepción cristiana que trajeron consigo los hispanos. [Palabras claves: Mayas, época colonial, concepción y medidas del tiempo.]

\begin{abstract}
"Lineages of lies": Loads of Centuries and Universal Times in the Maya colonial world. The encounter with the West and the imposition of new chronological and chronometric parameters, forced the Maya culture-always fascinated by the conception and recording of time - to adjust its parameters to the beliefs of its Spanish conquerors. Among the different strategies implemented, we can point out the redefinition of their ancient measurement system and the inclusion of their own historical events and processes within the providential and supposedly universal perceptions that characterized the Christian concepts brought by the Spaniards. [Key words: Maya, colonial period, conception and measurements of time.]
\end{abstract}

"Lignages de tromperie » : charges des siècles et temps universels dans les discours mayas coloniaux. La rencontre avec l'Occident, l'imposition de nouveaux paramètres chronologiques et chronométriques obligèrent la culture maya, depuis toujours fascinée par la conception et le registre du temps, à ajuster ses paramètres à la vision temporelle des conquérants espagnols. Parmi les diverses stratégies qu'elle adopta, se distinguent la redéfinition et resémantisation de son ancien système de mesure ainsi que l'insertion de ses propres événements et processus historiques dans la vision providentialiste et supposée universelle qui caractérisait la conception chrétienne introduite par les Espagnols. [Mots-clés : Maya, période coloniale, conception et mesures du temps.]

* Centro de Estudios Mayas, Instituto de Investigaciones Filológicas, Universidad Nacional Autónoma de México [mhruzs@gmail.com] 
¡Y ardió por el fuego el pueblo de Israel y los profetas! ¡La memoria de los katunes y los años fue tragada en la luna roja! ¡Roja luna roe de la tierra el linaje de los Tutulxiu!

Libro de Chilam Balam de Chumayel: Kahlay de la conquista, p. 22

En noviembre de 1814 la comarca del lago Atitlán, habitada por kaqchikeles, k'iche's y tzutuhiles, fue testigo de un proceso que ordenó realizar el Juzgado Eclesiástico de Sololá, que involucró a varios pueblos y a resultas del cual se tuvo noticia de 33 médicos ahcunes a quienes se acusó de llevar a cabo ceremonias con francos resabios idolátricos - disfrazadas bajo tintes cristianos-, aunando a las actividades terapéuticas, otras de "hechicería" (Chaclán 1989). Así, a más de asociar hierbas, ungüentos, ventosas y sangrías, con objetos de adivinación (cristales y semillas de colorín) de los que se valían desde antiguo, "mezclaban" las plegarias "malas" con otras dirigidas a Dios, a Jesucristo y a la Virgen, al tiempo que realizaban rituales tanto en las cruces de los caminos, los cementerios y las mismísimas iglesias, como en la vivienda del enfermo, los volcanes y montes cercanos, "llamándolos con el nombre de ahagüapp, que quiere decir señores", sin obviar la mención a otros cerros más alejados, a los que se invocaba al mismo tiempo que a los "abuelos difuntos", en torno a una mesa dispuesta en la casa del enfermo con manteles, velas, incensarios y los instrumentos de augurio, estando "todos los hijos con sus padres".

Para mayor escándalo en mayas tenidos por buenos cristianos, los especialistas confesaban a quienes solicitaban sus servicios y les exigían guardar sus actividades en secreto ante los españoles. Para normar sus rituales se valían de un calendario antiguo de dieciocho meses, con el cual mantenían esos que el eclesiástico encargado de la averiguación calificó como "linajes de embustes". Y embustes que no guardaban para sí, pues los ahcunes incrementaban sus saberes en reuniones con sus similares de otros pueblos, vecinos o incluso de la costa, y fomentaban su difusión instruyendo a alumnos.

Con independencia del calificativo de "embustes" que se endilgó a las actividades de los participantes, la invocación a "linajes" no parece desproporcionada, pues se trataba de prácticas, creencias y actitudes mantenidas a lo largo de centurias por generaciones de mayas, en un afán por acomodar sus propios mitos, historias y tradiciones en las cronologías y espacios de los nuevos

1. Se acusó asimismo a los ahcunes de emplear máscaras, realizar ceremonias en torno a los trajes de los bailes (en particular el del Tzunun) y a favor de los alcaldes recién electos, $\mathrm{y}$, en el pueblo de Atitlán, de guardar días de ayuno sexual para luego desfilar la noche previa a la fiesta patronal, con una calavera y "vestidos antiguos" (que guardaba en una caja el alcalde de la cofradía), borrachos y danzando al son de "un tamborcito y pito muy pausado", así como de reverenciar dos lienzos: uno que representaba "la cara que llamaban Diego Martín" y otro con la imagen de san Juan Bautista, y adorar al Sol y la Luna. 
"Linajes de embustes": cargas de centurias y tiempos universales en el mundo maya colonial

señores. Nada extraño en pueblos dotados desde antiguo de especialistas en el manejo del tiempo. Hoy, gracias a los nuevos estudios epigráficos, sabemos que ya desde siglos antes dichos especialistas "adecuaban" tal o cual periodo de tiempo, incluyendo los míticos, a fin de poder insertar las hazañas e incluso las genealogías de los gobernantes en turno de manera políticamente más efectista y efectiva, no sólo en el devenir, sino en ocasiones proyectándolas hasta el futuro, conforme lo permitía alguna concepción cíclica de la temporalidad.

La llegada de distintas concepciones temporales, procedentes de Occidente, modificó las posibilidades de manipular los calendarios, al tiempo que una distinta concepción de lo sacro tornó imposible seguir invocando filiaciones divinas para tal o cual personaje. No obstante, como han mostrado estudiosos como William F. Hanks y Laura Caso, aludiendo a los mayas peninsulares, tal modificación no conllevó la cancelación de adecuaciones; éstas continuaron haciéndose, si bien a partir de entonces con objetivos a menudo de orden comunitario y recurriendo a fuentes de inspiración europea. Así, en textos como el Chilam Balam de Ixil, por mencionar un ejemplo, vemos conjuntarse compases de los vientos con ruedas de katunes; almanaques, zodiacos y lunarios de origen medieval con ángeles cristianos y deidades mayas de los vientos; números romanos con guerras de katunes, o escudos de armas a la usanza heráldica europea con cosmogramas peninsulares (Caso 2011) ${ }^{2}$, al tiempo que si bien "The sheer quantity of documentation produced by Maya authors... indicates that although many of the colonial genres would be new, the act of writing and its multiple relations to governance and ritual practice were well know and rapidly transposable onto the new genres" (Hanks 2010, p. 91).

Es objetivo del presente ensayo ilustrar algunos de los supuestos anteriores, en particular el cómo se dieron varias de esas transposiciones en géneros de corte histórico como las probanzas, memoriales y "reportorios", tanto como en otros de carácter más bien lingüístico, como artes y vocabularios, sin desdeñar la mención a reportes civiles y eclesiásticos hispanos. A fin de mostrar convergencias y divergencias en el extenso ámbito geográfico habitado por los pueblos mayas, se aludirá a varios de ellos, haciendo hincapié en documentos de la Audiencia de Guatemala, menos conocidos que los procedentes de la Gobernación de Yucatán. Su novedad explica también el que se haya optado por citarlos en ocasiones con cierto detalle, a fin no sólo de brindar al lector elementos que le permitan apreciar en forma más nítida su valor, sino buscando también privilegiar las expresiones escritas de los propios mayas.

2. A más de la acuciosa edición que hizo Laura Caso del Chilam Balam de Ixil (2011), pueden consultarse, para una visión breve y con fines de divulgación pero bien lograda, el artículo de Velázquez (2010), y el texto ya clásico de Bricker y Miram sobre el Chilam Balam de Kaua (2002), a más de la edición de Gubler y Bolles del Chilam Balam de Na (2002). 

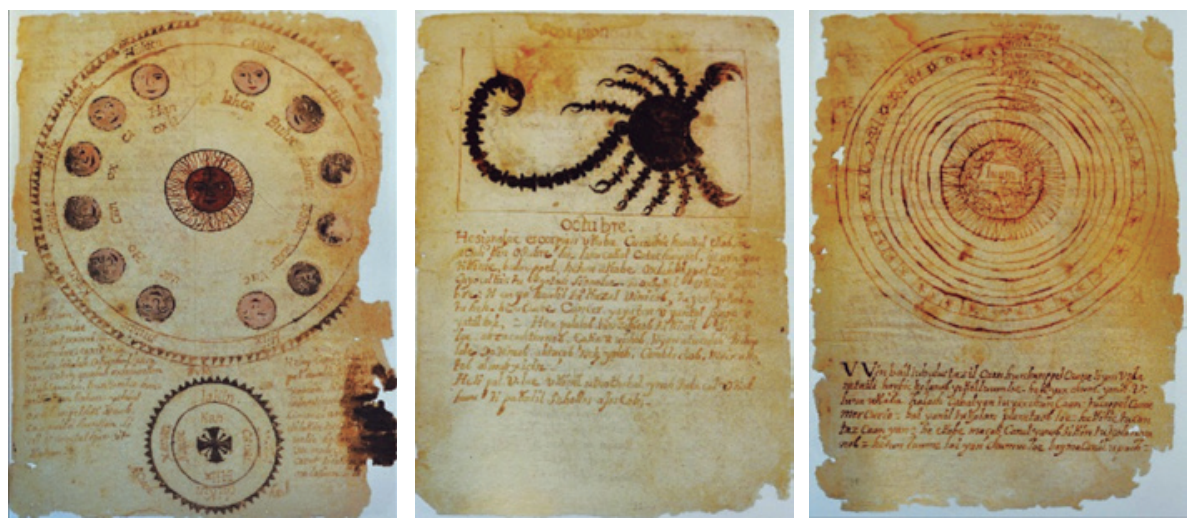

Fig. 1 - Imágenes del Chilam Balam de Ixil (Laura Caso 2011).

\section{Tinta hispana para cronovisiones mayas}

Conviene iniciar señalando que, al tratarse de cronovisiones, cronometrías y cronotopos distintos, no sorprende que las mensuras mayas desbordaran a menudo los esquemas cronológicos trazados por Occidente, yendo incluso, en el caso de los tiempos individuales, más allá de la existencia terrena, ya que entre ellos también los muertos saben de temporalidades ${ }^{3}$. Unos y otros se beneficiarían, pues, de la dádiva de Ah dza kin-al, entidad que en el Diccionario de Viena (maya yucateco) se vertió al castellano como "el dador de la vida que es Dios" (Álvarez 1984), pero, a juzgar por su nombre, en sentido estricto lo que la deidad otorga $[d z a]$ es tiempo [kin], con independencia de las formas de vida y existencia.

La manera en que los pueblos mayas concibieron y nombraron tales temporalidades bajo el dominio hispano es sin duda tema requerido de profunda investigación, que, carente de tiempo y espacio, ni por asomo pretendo abarcar aquí dada su complejidad, derivada no sólo de la naturaleza del tópico, sino del hecho de que carecemos de fuentes suficientes para aprehender el amplio campo semántico que abarcó el concepto tras los inicios de la colonización ${ }^{4}$, periodo particularmente importante para la adecuación de cronovisiones muy disímiles, de lo cual dan cuenta los textos escritos durante la Colonia, por escribanos tanto mayas como hispanos.

3. Por desgracia no puedo detenerme en este punto, e ilustrar cómo los muertos no sólo poseen identidades otorgadas por el espacio que ocupan, sino que experimentan cambios identitarios diacrónicos, ni tampoco abordar las diversas concepciones mayas acerca de la manera en que los difuntos viven el tiempo. Remito al interesado a un texto previo (Ruz 2003).

4. Y el intento se torna aún más arduo cuando se intenta aprehenderlo desde las distintas lenguas mayas, que si bien muestran rasgos comunes también exhiben numerosas peculiaridades. 
"Linajes de embustes": cargas de centurias y tiempos universales en el mundo maya colonial

Recurriendo a los vocabularios y artes -redactados por lo común por frailes avezados, en quienes delegaban tal tarea sus superiores- podemos atisbar, por ejemplo, en las formas maya yucatecas de concebir las divisiones de días y noches por "cuerdas", los distintos clasificadores en boga para mesurar el transcurrir temporal (como los sufijos -buk, -piz, -te) o sus intervalos (por ejemplo te-el, -yam), las voces que marcaban tiempos cotidianos y extraordinarios, fastos o infaustos, o aquellas que aluden a peculiaridades meteorológicas que intervenían en la concepción de ciertas expresiones del tiempo, y la manera en que varios de tales elementos se conjugaban para normar, hasta donde fuese posible, actividades agrícolas, de caza, pesca y recolección, por no hablar de las de naturaleza ritual y social, incluyendo la esfera de lo jurídico. ¿No se traduce acaso "sentencia" como xot kin: "cortar el tiempo"?

Retengamos apenas, meros ejemplos y burda simplificación, que a más de la continua asociación día/sol (kin) y noche/oscuridad (ek), en los vocabularios yucatecos se advierten numerosos marcadores que dan cuenta de particiones ${ }^{5}$. De ello dan constancia voces como las que nombran al periodo que va de sol a sol, cuando -junto con el astro- se sumerge el día (bul kin), cuando se "tapa" ( hu-mac kin) o "cierra" (kalab kin), dando fin al lapso que transcurre del amanecer hasta el crepúsculo (ek okin et akab). Periodo, éste, claro y sereno si lo había regido un sol "sosegado" (leman kin; lemec-nac kin), propicio para llevar a cabo una jornada cualquiera de trabajo (man-kin-al), que los frailes bien cuidaron de diferenciar de los domingos, ahora concebidos como de obligatorio descanso, explicitando que, a diferencia del día laborable o común (piz kin), dentro del nuevo esquema de semanas se trataba de momentos de "pasa fiesta" (u kin man-kin-al); días dedicados al Señor según lo marcaban sus propios nombres castellanos: domínica, domingo (del latín dominus), para lo cual se valieron de la expresión maya $u$ kin ku: el día de dios.

El "cada día, todos los días" designado por u xoc-an kin-il [su cuenta su día], se dividía a su vez, tal como él mismo "dividía” en partes la tierra (hatz cab) y, con ella, el transcurrir cotidiano de quienes la habitaban. Los tiempos en que este devenir diurno se fragmentaba parecen anclarse en la idea de la existencia de "pasos" dados por el astro durante su recorrido; pasos medibles por arcos de distancia o cuerdas $(t a b)$, como se hace expreso en las maneras de preguntar por el tiempo: tab yan kin (cuerda- está -sol), lo que los diccionarios traducen como "¿Qué hora es del día?”. De ello surgiría una división en cuatro "pasos": el amanecer (ahal cab: despertar-tierra), la mañana (kin: tiempo del sol por excelencia), el medio día (zuhuy kin; acaso vinculado con zuhuyil: virginidad, cosa virginal) y el atardecer (tzelep kin: de tzelep, inclinarse).

5. Para aproximarse de manera sencilla y rápida a los principales vocabularios en maya colonial, por campos semánticos, resulta de gran utilidad el trabajo de Álvarez 1984. 
El que tales "pasos" correspondían a la travesía solar por la bóveda celeste (tal y como el transitar de la Luna marcaba las temporalidades nocturnas) se corrobora incluso por algunas cosmovisiones de pueblos contemporáneos de filiación maya, como el chontal y el tojolab'al, que consideran que al mediodía el astro, en el cenit, se sienta a descansar. Por algo los tojolab'ales denominan a ese momento $k$ 'ulan $k$ 'au: sol sentado. Momento de particular peligro ya que a lo largo de él el Sol, descansando, se desentiende por así decirlo del orbe, al tiempo que se abren las puertas del Inframundo por donde salen entes sobrenaturales potencialmente dañinos ${ }^{6}$. Y no está de más recordar que en la tradición nahua el mediodía era justo el momento en que los portadores del astro rey asentaban, para descansar, las andas en que lo transportaban, y que incluso en la Europa medieval se tenía la creencia de que a las 12 del día y 12 de la noche se abrían las puertas del Infierno, posibilitando así la salida de fuerzas nocivas. No en balde, para contrarrestarlas, surgió la costumbre de entonar el Ángelus al mediodía, como se estila aún hoy en diversos espacios, no sólo rurales sino hasta urbanos, incluida la ciudad de Mérida $^{7}$. Buena muestra sin duda de cómo diversas culturas coinciden en el afán de lograr eso que los mayas yucatecos denominaban tzool-an be: "el orden-ado camino".

\section{Conjunciones y difusiones calendáricas}

Ese afán por "ordenar" el camino conjuntando cronologías se intentó desde fechas tempranas, pues al mismo tiempo que los recién llegados buscaron trasvasar al alfabeto latino los conceptos mesoamericanos acerca de la temporalidad y ubicarlos en sus propios calendarios, en las obras escritas por mayas empleando grafías y tintas hispanas vemos que, sin dejar de remitir a esquemas previos, no se desdeñaba la adopción de otros nuevos. Claros ejemplos son, por citar algunos bien conocidos, las "traducciones" - por llamarlas de algún modo-del sistema calendárico maya al calendario festivo católico que aparecen en El Título de Totonicapan ${ }^{8}$, o las interesantísimas amalgamas maya-occidentales de que dan cuenta los Chilam Balam a las que aludí antes.

6. De allí que los campesinos apegados a la tradición detengan sus labores y aprovechen para tomar la bebida de maíz que les ayuda a reponer fuerzas; pichí para los tojolabales; pozol o chorote (de maíz y cacao) para los chontales.

7. Ejemplo de ello es la ciudad de Mérida donde, a esa hora, varias radiodifusoras emiten el saludo angélico a María.

8. Donde se apuntan equivalencias como: 1 Tziquín, día de Santiago [25 de julio], 7 Camey, día de San Francisco [4 de octubre]. Cabe señalar que respeté las grafías que muestran los textos, comenzando por el registro de voces como Totonicapan, que en ocasiones figura como Totonicapán. Es de destacar también que el "Título" de ese mismo sitio aparece mencionado como Título de Totonicapán, y como Título de los señores de Totonicapan. 
"Linajes de embustes": cargas de centurias y tiempos universales en el mundo maya colonial

Ciertamente la recurrencia a marcadores antiguos parece ser más frecuente en aquellos pasajes de los textos que dan cuenta de sucesos tempranos, y si bien resulta tentador suponer que se tratase de una elección deliberada, es difícil asegurarlo. Los kaqchikeles, por ejemplo, dieron cuenta en sus Anales de varios sucesos de la conquista usando sólo fechas de su propio sistema. Así, consignaron que fue un día 1 Ganel cuando los hispanos comandados por Pedro de Alvarado destruyeron a los k'iche's, en tanto que el Memorial de Sololá apunta que "El día 4 Qat los reyes Ahpop y Ahpop Qamahay fueron quemados por Tonatiuh", y 35 días más tarde, el 1 Hunahpú, entraron los invasores a la capital, Yximché. Un 7 Ahmak (7 de mayo de 1530), después de cinco años y cuatro meses de estar "bajo los árboles, bajo los bejucos", los grandes señores kaqchikeles junto con muchos otros principales saldrían rumbo a Panchoy para rendirse ante Alvarado un 8 Noh ( 8 de mayo). Tras sufrir numerosas vejaciones, serían arteramente asesinados ${ }^{9}$.

Los mayas peninsulares, por su parte, narraron el encuentro con los hispanos con una doble marcación, señalando la fecha maya, regida por los katunes, junto con aquella de los años occidentales, señoreados por el nacimiento de Cristo. Así, el Chilam Balam de Chumayel asienta: "Once Ahau. Llegaron los 'hombres de Dios', del Oriente, los que trajeron el dolor. Su primer principio, aquí en la tierra de nosotros, los hombres mayas, fue en el año de 1513 años" (ChBCh, p. 137). Como puede observarse, la fecha no corresponde a la del encuentro inicial con españoles (1511, el naufragio del grupo de Valdivia), ni al primer desembarco hispano en la Península, por Cabo Catoche (1517, al mando de Hernández de Córdoba), pero la exacta marcación cronológica según los parámetros occidentales no parece preocupar demasiado a quienes registraron el hecho; como si lo trascendental fuese consignar el katún con su carga. Por algo se advierte en el mismo texto que grandes sacerdotes como Nahau Pech, Napuc Tun, Chilam Balam, Ah Kuil Chel y Natzin-Yabun-Chan, habían "manifestado las cargas de las penas" para cuando llegaran los cristianos: "vómitos de sangre, pestes, sequías, años de langosta, viruelas, la carga de la miseria, el pleito del Diablo" (ChBCh, p. 182).

Conforme avanzaba el tiempo, parecen haberse ido privilegiando los esquemas europeos ${ }^{10}$, pero tal dilución - por llamarla de algún modo- no presupuso la desaparición total de los parámetros de mensura previos. De hecho, aún hoy es posible encontrar comunidades donde siguen vigentes calendarios

9. Se registra, por ejemplo, que fue un 4 Can cuando al señor de Yximché, Chuuy Tziquinú, "lo condujeron por el camino y lo ahorcaron secretamente" (Memorial... 1980, p. 124-138).

10. Así, en una copia tardía del Manuscrito de Chan Cah (siglo xIx) primará el zodiaco, conjugándolo con las antiguas predicciones calendáricas, en tanto que las alusiones a la conquista se limitarán a la fecha de llegada de los españoles (1982, p. 26 y 124). 
prehispánicos, o al menos porciones de ellos, como en el macizo montañoso de Los Cuchumatanes.

Del continuo empleo de calendarios y "reportorios antiguos" a lo largo de la época colonial dan fe varios escritos eclesiásticos, en correspondencia con el afán de la Iglesia por desterrar el empleo de "antiguallas" que, no sin razón, se consideraban refugio para conductas y conceptos vinculados con esquemas religiosos previos, en tanto posibilitaban, por ejemplo, fijar épocas propicias para llevar a cabo los rituales o pronosticar sucesos por venir. Harto conocida es la referencia de Diego de Landa, acerca de cómo, empleando el sistema de katunes, los mayas lograban tener "a maravilla, cuenta de sus edades", así como la lista que nos legó con los nombres de los días y el bosquejo de una rueda de katunes que ilustra una cuenta corta; pobre remedo de las imágenes que debían de contener los códices que quemó ${ }^{11}$.

Pero la de Landa no fue la única noticia en ese sentido: en su Novena Carta Pastoral, Francisco Núñez de La Vega, obispo de Chiapa y Soconusco, asienta que en su Diócesis, a través de los calendarios, "regulan los nacimientos de los hombres" al observar la época en que sucedían y pronosticando, según ésta, "el estado, condición y sucesos prósperos o adversos de la vida que ha de tener cada uno y el modo con que han de gobernarla en sus acciones", asignándoles el nagual correspondiente al día de su nacimiento (Núñez 1989, p. 753). En una carta enviada hacia 1689 al Marqués de los Veles, presidente del Consejo de Indias, el diocesano apuntó haber recogido "una manta pintada muy antigua", una "rueda a modo de la pitagórica", y otras piezas, "tanto escritas en libros como esculpidas en lápidas, así como finalmente en lienzos...", y "más de 30 libros", acotando que los indios mantenían el asunto con tal secreto que hasta ese entonces no se había "tenido noticia de que por arte estuviese puesta la superstición con reportorio y calendario en forma, al modo de la astrología judiciaria, con los signos y figuras pintadas", con la diferencia de que aquí, en vez de astros, se pronosticaba por animales terrestres, que, en su opinión, eran naguales. Como muestra de ello le envió "un cuaderno donde están pintadas las figuras de algunos animales; de sapos, monos y culebras, que daban por naguales a los niños", solicitándole "haga vuestra excelencia que se queme luego el calendario y cuadernillo que va incluso, pues sólo por lo superior de su persona y puesto lo remito, con el sigilo que estas materias piden" (Núñez, op. cit., p. 209-210).

A tales materiales se sumaban "otros papeles en que estaban en su idioma las invocaciones con que llamaban al Demonio", todo ello custodiado por los que califica de "sabios de los pueblos", quienes transmitían el conocimiento a

11. Es bien conocida su reflexión: "Hallámosles gran número de libros de estas sus letras, y porque no tenían cosa en que no hubiese superstición y falsedades del Demonio, se los quemamos todos, lo cual sintieron a maravilla y les dio mucha pena" (Landa 1978, p. 105). 
"Linajes de embustes": cargas de centurias y tiempos universales en el mundo maya colonial

sujetos considerados capaces por haber nacido en determinada fecha calendárica y que aprendían al mismo tiempo tanto los aspectos religiosos (incluida la escritura de caracteres) como los ligados a la herbolaria, sendas partes del proceso terapéutico. En febrero de 1693, en un informe enviado al Vaticano, la cifra de "calendarios de supersticiones o libros de adivinación" recogidos (y destruidos) había ascendido a "más de 200"12, y aunque es probable que el dato sea exagerado, nos habla de la vigencia y riqueza de la tradición de escritura y pictografía indígena chiapaneca ${ }^{13}$.

Según apunta en sus Constituciones Diocesanas, el obispo hizo traducir algunos de los materiales por indígenas, sobre todo "maestros de la superstición", "para enterarme bien de sus errores y poder convencerlos con individual y fundamental inteligencia". Supo así que existía una división de 18 meses de 20 días, a los que se agregaba otro periodo de cinco días que en año bisiesto se aumentaba a seis ${ }^{14}$, y que los nombres de los días "están por el orden siguiente: Mox (alias Ninus), Ygh, Votán, Ghanan, Abagh, Tox, Moxic, Lambat, Molo (en otros Mulu), Elab, Batz, Euob, Been, Hix, Tziquín, Chabín, Chic, Chinax, Cahogh, Aghual" (Núñez, op. cit., p. 276) ${ }^{15}$.

Puesto que ya están publicadas, no me detengo en las notas que el prelado dedica a algunos de los personajes que dieron nombre a los días. Recuerdo tan sólo 1) su insistencia en identificar al Ninus que aparece en la Biblia con Imox, el primero de la lista, cuyo culto relaciona con la ceiba, considerada como origen del linaje, 2) la importancia que concede a Votán, el "tercer gentil", "señor del palo hueco" o tepanaguaste, "corazón de los pueblos", que sabemos vinculado con la oscuridad, los montes, el interior de la tierra y las cuevas (sitios todos de transición con el inframundo), 3) la alusión que hace a los cuatro cargadores, aquellos por los cuales "se hacen la cuenta por meses y días en los más de los calendarios 16 " y que, según asienta, eran "los más celebrados y venerados", y 4) el que mencione que en los cuadernillos que hablaban de Hicalahau [Ik'al

12. Archivio Segreto Vaticano, Visitas ad limina, Sacrae Congregatione Concillii, Relationes 218, "Relación de la diócesis de Chiapa y Soconusco, 24 de febrero de 1693", en latín (Véase Ruz 1999).

13. Si bien el obispo informó al Vaticano haber destruido los calendarios y cuadernos (y recomendó al presidente del Consejo de Indias hacer lo mismo con el que le envió), un siglo después el clérigo Ramón Ordóñez y Aguiar aseguró tener uno de ellos, la famosa Probanza de Votán, en el que se basó para su Historia de la creación del cielo y de la tierra, tan abigarrada como compleja, y por partes francamente fantasiosa.

14. No le escapó su similitud con los empleados en la zona del altiplano.

15. Mantengo las grafías del original, y recuerdo que si bien los nombres se mencionan asociados a pueblos como Oxchuc, Teopisca y Comitán, donde durante la colonia vivieron tzeltales, Campbell sugiere como "muy probable que la lista sea kanjobalana y posiblemente del motozintleco mismo", asegurando que: "por lo menos esta lista no es tzeltal, contrariamente a lo que casi todos han supuesto" (1981, p. 17).

16. Es de suponer equivalentes a los ah cuch haab de los yucatecos. 
Ajaw], un temido dios negro, y Coslahuantox [Oxlajuntox], figuraban "siete negritos [empleados] para hacer divinaciones y pronósticos correspondientes a los siete días de la semana”. De ser cierta la aseveración, estaría hablando de un ajuste de los antiguos calendarios adivinatorios a la concepción occidental del tiempo dividido en semanas, pues incluso dos décadas después (1723) fray Juan de Rodaz, profundo conocedor de la región y autor del Arte de lengua tzotzlem o tzinacanteca, con explicación del año solar y un traslado de las quentas de los indios, alertaba: "Nota que estos naturales no tienen nombres de semanas ni quentan por ellas, si no es aprovechándose del número septenal, según el qual llaman a la semana zhucquin [séptimo-día]" (Apud Ruz 1989, p. 153).

Modificados o no, los calendarios circulaban también en el obispado de Guatemala. Fray Thomas Coto, en su justamente célebre Thesaurus verborum (ca 1656) tras traducir "calendario" como Vuh ahilabal 3ik, "libro para contar los días", añadió como ejemplo: nima ah tih qo S[an] Antonio, rohonel r'etam ru chahim Vuh ahilabal 3ik: "Un gran sabio hay en San Antonio, todos saben que guarda un libro para contar los días" (Coto 1983, p. 83). La aseveración "todos saben" se antoja bien aplicada, pues en los escritos coloniales abundan las referencias al empleo de artes adivinatorias a lo largo y ancho de la Audiencia de Guatemala, y al hecho de que de ello estaban enteradas las autoridades religiosas y civiles, hispanas e indias por igual, amén de que se constata la recurrencia a ellas de todos los estratos sociales y grupos étnicos, incluyendo a los europeos.

Por eso, a lo largo de la Colonia, para desterrar conductas que se consideraban idolátricas o supersticiosas, los obispos inquirían una y otra vez sobre el tema a sus curas y feligreses. Juan de Sancto Mathía, por ejemplo, con motivo de su visita pastoral en 1670, emitió un auto ordenando a los párrocos informar si en los pueblos bajo su cargo había "sortílegos o hechiceros o brujos o que usen de algunas otras supersticiones, o sean conjuradores de nublados o tempestades, o si con agua, artesa o cedazo u otras maneras de hechicería declaran los pensamientos o voluntad de otros... o si usan de nóminas y en ellas escritos de palabras o nombres no conocidos..." (Ruz et al. 2002, p. 49). Y en 1687 su sucesor, Andrés de Las Navas, alertó al presidente de la Audiencia sobre la "relajación" que en términos de doctrina campeaba no sólo en las zonas más alejadas de las instancias hispanas, como los Cuchumatanes y las Verapaces, sino incluso en regiones inmediatas a la capital, como los pueblos del Valle de Guatemala, y anexó a su escrito la información que había podido recabar entre sus párrocos. El de San Juan Comalapa, por citar un caso, denunció la persistencia de "supersticiones" y rituales "idolátricos", vinculados en particular con el empleo de calendarios prehispánicos y artes adivinatorias a las que se recurría en embarazos, partos, enfermedades y actividades agrícolas (Ruz en preparación). La noticia no era nueva para el diocesano: cuatro años antes había recibido de manos del doctrinero de San Bernardino Patzún un 
"Linajes de embustes": cargas de centurias y tiempos universales en el mundo maya colonial

"cierto cuadernillo calendario en lengua kacchiquel, por el cual dijo se rigen y gobiernan los indios de este y otros pueblos, para los días que eligen y guardan en sus abusos"; calendario que mandó traducir ${ }^{17}$.

A fin de ahondar sobre los métodos empleados por los "contadores de los días" para llevar a cabo sus adivinaciones, ese mismo 1687 Las Navas hizo tomar declaración "secreta y apartadamente" a Juan Maca, vecino del pueblo de Chimaltenango, tenido por "buen cristiano y de buena conciencia", quien declaró estar bien enterado "de ciertos indios e indias de este dicho pueblo que usan de supersticiones e idolatrías, dando a entender a los demás indios e indias de él [que] son sahorines ${ }^{18} \mathrm{y}$ adivinan los días y tiempos más a propósito para sembrar o coger [cosechar] y hacer otras cosas, y que por ello son muy seguidos de los demás indios del pueblo, y para hacer lo que les advierten y dicen..."

Y que a éstos llaman cholol qih, cuyo término entre los demás indios de este pueblo es muy secreto y quiere decir en castilla "contadores de días" y sahorines. Y que lo que pasa con éstos es que los demás indios del pueblo van a ellos al tiempo de sus sembrados de maíz o cuando ha de parir alguna india o para hacer otra cualquiera cosa, y les preguntan qué día es bueno para hacerlo y ellos se lo dicen por tener puestos sus nombres a los días; que a uno le llaman conejos, a otro pájaros, a otro dientes, a otro tigre, a otro león, a otro lagarto, a otro Tres Cerbatanas y a otro de Doce Perros, teniendo por buenos días al de muchos conejos y al de muchos dientes, a los cuales escogen para lo referido.

[...] Y que cuando los religiosos les predican en la iglesia y les amonestan que dejen las supersticiones y antigüedades, después de que salen de la iglesia unos con otros dicen "¿Que por qué han de dejar lo de sus abuelos y antepasados?" (Ruz, en preparación).

Ciertamente, no lo dejaron. En 1704, el franciscano Antonio Margil de Jesús, fanático persecutor de "herejes" e "idólatras", reportaba que durante una visita a los pueblos k'iche's y zutuhiles de Suchitepéquez encontró nada menos que 600 ajkunes o curanderos, regidos por 14 "obispos" y cinco "papas", incluyendo entre los penitenciados a "dos grandes nahuales" que habían sembrado el terror en la comarca en figura de "tigre", matando entre 10 y 12 indios en dos años (y no fueron más allá gracias que muchos otros se habían defendido). Aprovechaban sin duda para ello el día Kan, tenido como específico para la iniciación al nahualismo y para "transformarse en animales fieros" (Sáenz de Santa María 1981, p. 445-460).

17. Por auto emitido por Las Navas en San Bernardino Pazón [Patzún], el 5 de noviembre de 1683, se ordenó al alférez Felipe Roldán de la Cueva hacer la traducción y ponerla "al pie de este auto, para que sea reconocido su contenido", pero ésta no consta en el expediente (AHAG, Tramo 2, Caja 87. Sección sin clasificar; exp. 305 de un legajo que contiene autos emitidos por los diocesanos de Guatemala).

18. Zahorí: persona capaz de descubrir lo oculto. Del árabe zuharí, geomántico (Moliner 1988, II: 1570, entrada “zahor'”). 
Los calificados como “obispos”, por su parte, disponían cuándo y cómo habían de recibirse los sacramentos cristianos y como contrapartida del bautismo señalaban al niño un "nahual", en fecha que determinaban guiándose por los repositorios ${ }^{19}$. A decir del franciscano, los "papas", cumbre de la jerarquía sacerdotal del área, conocían a la perfección los calendarios cristiano y pagano; conocimiento de particular importancia para el desempeño de su labor. Apuntó haber quemado tales calendarios, junto con imágenes de deidades ("ídolos"), huesos, chalchihuites cincelados ("algunos con raro artificio"), aras, sillas, "bancos encantados y variedad de zarandajas", algunas de las cuales constó ser herencias familiares que venían desde antes de la conquista. Pero aclaró que no se hacía demasiadas ilusiones: la mayor parte de la sabiduría "calendárica" estaba en la mente de los chololkij, los contadores de los días (ibid.).

El alcalde mayor de San Antonio agregaría que cuatro de los "papas”, ciegos, eran además grandes "astrólogos" y que a algunos niños "los señalaban detrás de las orejas para dar a entender que serían grandes entre ellos", mientras que Margil especificó que Juan Qucée, uno de los grandes "brujos”, había dado a Francisco Aquemo, un "discípulo" que tenía en el pueblo de San Bernardino, un "arte" para que lo escondiese ${ }^{20}$, buena muestra de que el conocimiento calendárico se trasmitía generacionalmente, y del empeño que ponían los mayas de Guatemala en preservarlo ${ }^{21}$.

Y lo preservaron a tal punto que siguió vigente todo el tiempo que duró el dominio hispano, como lo muestra el espléndido documento relativo a la jurisdicción de Sololá entre 1814 y 1820 al que aludí en los párrafos iniciales, que es sin duda un excelente compendio de las actividades rituales de la época colonial justo en su crepúsculo.

Respecto al tema que aquí nos interesa, en ese proceso se acusó a los denunciados de usar "de ciertas piedrecitas y frijoles colorados con que contaban los días del mes [dotados] con ciertos nombres en que profetizaban o adivinaban la muerte o la vida de los enfermos; que también usaban de incienso, candelas, y responsos, que solían poner en ciertos días pidiendo la muerte o la vida de los que se encomendaban o creían en ellos". Domingo Rodrigues, "maestro de

19. Otro tanto fue reportado en tiempos del obispo Las Navas en Rabinal, cuyos pobladores aceptaban bautizar a sus niños sólo después de haber consultado al adivino local acerca de la tona (animal compañero) que les correspondía según el calendario prehispánico (Ruz 1997, p. 59).

20. Como se negó a revelar dónde guardaba el texto, el fraile ordenó que el mancebo fuese desterrado del pueblo junto con dos "papas" (Sáenz de Santa María, op. cit., p. 492, 496).

21. Muy distinta era la situación en Yucatán. En abril de 1813 Bartolomé del Granado Baeza, cura de Yaxcabá, apuntaba que los mayas de la región "Para conocer las estaciones del año, no tienen ya otro calendario más que el nuestro, porque de sus calendarios antiguos no hay memoria" (1946). Cabe recordar que dos siglos antes Sánchez de Aguilar había reportado el uso de "libros" entre sus feligreses, de uno de los cuales incluso se apropió (1987, p. 95). 
"Linajes de embustes": cargas de centurias y tiempos universales en el mundo maya colonial

coro, alcalde de [la] cofradía de Consepción, e indio muy racional", reveló que al pueblo de San Pedro "venía cada semana un yndio de San Francisco llamado Domingo Santo", el cual, teniendo también a la vista los frijoles, "comensava á llamar los días del mes".

Gracias a sus declaraciones y las de otros testigos se pudo saber que el día denominado $\mathrm{Ah}^{22}$ se conceptuaba como bueno "para poner responsos..., haser oraciones y prender candelas en la yglesia; que Ell era "muy fuerte y bueno para quemar copal en los montes para pedir la salud, y que los que nasen en este día son muy fuertes, que son los susezores de los superticiosos ò brujos, y que á estos los enseñan ellos mismos desde pequeños"; el tercer día, Quieli, era igualmente propicio, por lo que los nacidos en él serían ricos en bestias y dinero. Cán e Yx, por su parte, eran favorables para realizar rituales en el monte; Bátz, el sexto, era mal día por pronosticar muerte, y en él nacían brujos y "supersticiosos" 23 , mientras que en Ahpúp veían la luz "los tiradores o cazadores" y en Tziquín, el octavo, los que serían "colmeneros o cogedores de pájaros en los montes". Los dos días siguientes tenían que ver con menesteres femeninos de alguna manera vinculados a la fertilidad: Tzii, día del perro, "pronostica que las mujeres que nacen en él son rameras y muy dadas á la sensualidad", en tanto que el décimo, Caüoc, "pronostica que han de ser parteras". Los que nacían en los dos que venían después, Toh y Canél, serían sembradores, "muy ricos de maíz y otros granos", mientras que Noh e Ymóx, eran días "muy fuertes en que van a los montes a sus incuras $[\mathrm{sic}]$ oraciones, en que enseñan a sus discípulos y hacen otras diabluras". Quienes naciesen bajo Cat, el décimoquinto, serían "muy pobres y gueniados [sic]".

\begin{tabular}{|c|c|c|c|}
\hline $\begin{array}{l}\text { Memorial } \\
\text { de Sololá }\end{array}$ & $\begin{array}{c}\text { Sololá } \\
(1814-1820) *\end{array}$ & $\begin{array}{l}\text { K'iche' } \\
\text { actual** }\end{array}$ & $\begin{array}{l}\text { Núñez de la Vega } \\
\quad(1702) * * *\end{array}$ \\
\hline \multicolumn{2}{|c|}{ lengua k'iche' } & \multicolumn{2}{|c|}{$\begin{array}{c}\text { lengua de Chiapas } \\
\text { (probable kanjobalana, ver nota 15) }\end{array}$} \\
\hline $\mathrm{Ah}$ & $\mathrm{Ah}$ & Aaj & \\
\hline Ey & Ell & Ee' & \\
\hline Queh & Quieli $^{24}$ & Keej & \\
\hline
\end{tabular}

22. Mantengo los nombres como figuran en la transcripción del documento.

23. “... que al que declara, le nació un hijo ahora un año, que le llamó José Miguel, y que luego le dixeron los del arte que había de ser brujo, y que así no los persiguiera á ellos; pero que el no creé en eso, y que por lo mismo tiene llenos á sus hijos de evangelios y rosarios, principalmente al chiquito, que va a criarlo con mucho cuidado y do[c]trina para que no se verifique lo que le dijo el hombre malo".

24. Es de suponer estamos ante una consignación errónea de parte del escribano o una lectura incorrecta por parte del paleógrafo, y que se tratase de Quieh, interpretándose la "h" como "li", en caso de hallarse estos dos rasgos unidos. 
Mario Humberto Ruz

\begin{tabular}{|c|c|c|c|}
\hline $\begin{array}{l}\text { Memorial } \\
\text { de Sololá }\end{array}$ & $\begin{array}{c}\text { Sololá } \\
(1814-1820) *\end{array}$ & $\begin{array}{l}\text { K'iche' } \\
\text { actual** }\end{array}$ & $\begin{array}{l}\text { Núñez de la Vega } \\
\text { (1702) } * * *\end{array}$ \\
\hline \multirow[t]{3}{*}{ Can } & Cán & Kaan & \\
\hline & $Y x$ & I’x & Hix \\
\hline & Batz & B'aatz' & Batz \\
\hline Hunahpú & Ahpúp & Ajpuu & \\
\hline Tziquín & Tziquín & Tz'ikin & Tziquín \\
\hline Tzíi & Tzii & Tz'i & \\
\hline \multirow[t]{2}{*}{ Caok, Coak } & Caüoc & Kawoq & Cahogh \\
\hline & Toh & Tooj & Tox \\
\hline Ganel & Canél & Q'anil & \\
\hline Noh & Noh & No'j & \\
\hline Ymox & Ymóx & Imox & Ymos, Mox \\
\hline Qat & Cat & K'at & \\
\hline $\mathrm{Iq}, \mathrm{Yq}$ & & Iiq' & Ygh \\
\hline Akbal & & Aq'ab'aal & \\
\hline Camey & & Kamee & \\
\hline Ahmak & & Ajmaq & \\
\hline \multirow[t]{14}{*}{ Tihax } & & Tijaax & \\
\hline & & & Votán \\
\hline & & & Ghanan \\
\hline & & & Abagh \\
\hline & & & Moxic \\
\hline & & & Lambat \\
\hline & & & Molo o Mulu \\
\hline & & & Elab \\
\hline & & & Euob \\
\hline & & & Been \\
\hline & & & Chabín \\
\hline & & & Chic \\
\hline & & & Chinax \\
\hline & & & Aghual \\
\hline
\end{tabular}

Tabla 1 - Nombres de los días calendáricos

* apud Chaclán 1989, ** Craveri 2010, *** Núñez de la Vega, op. cit., p. 276. 
"Linajes de embustes": cargas de centurias y tiempos universales en el mundo maya colonial

Quienes declararon no pudieron dar mayor razón de los días restantes, pero sí señalaron que los ahcunes enseñaban el oficio -en ocasiones a sus yernos- dejando en herencia a los alumnos sus instrumentos médicos, los enseres adivinatorios y los "papeles en que tienen escritos los nombres del mes". Dato de interés es que el ya citado Domingo Rodrigues, testigo particularmente conocedor, precisó que "al llamar los días del mes... algunos los cuentan de veinte días y otros de dies y seis, por sus nombres".

Como puede observarse, pese a su parquedad la información remite en su mayoría al cholk'iij de 260 días $^{25}$, cuyo empleo por los kaqchikeles coloniales a manera de "libros" para normar o interpretar algunos métodos adivinatorios (como el que recurría a las semillas de colorín o $t z i$ ' $t e^{26}$, denominado precisamente $t z i$ 'te q’amwuj), había sido ya registrado por Hill, quien especifica existían también ciertos calendarios llamados q'amutz para programar los rituales comunitarios (Hill 2001, p. 124 ss.). Es difícil saber, empero, si a tal diferencia pudiese corresponder la precisión del "muy racional" maestro de coro Domingo Rodrigues, ciertamente novedosa, de que algunos usaban listas de 20 días, y otros de 16. Lo que sí sabemos es que usar calendarios está aún en boga en poblados k’iche's, kaqchikeles, achíes, ixiles, kanjobales y mames, usando prácticamente los mismos nombres y empleando los mismos "frijoles colorados" (semillas de colorín) y los cristales de cuarzo que los documentos coloniales califican de "ciertas piedrecitas", que representan a los dueños de los días ${ }^{27}$.
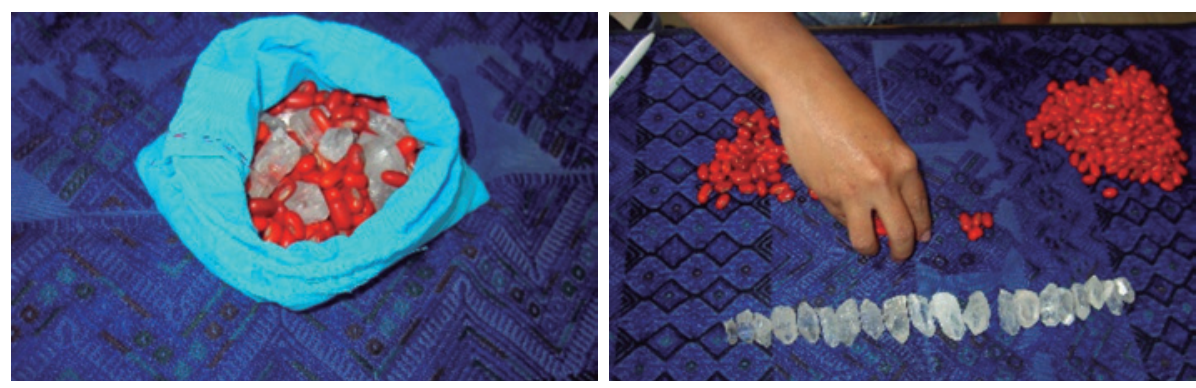

Fig. 2 - Baraj o bulto sagrado, con las 260 semillas de $t z$ 'ite' usadas para las adivinaciones y los 20 cristales de los nawales de los días, que se disponen sobre la mesa para luego colocar las semillas en hileras de siete grupos de cuatro semillas cada uno (Michela Craveri, (C) Craveri [en Sotelo y Craveri 2013]).

25. Literalmente "acomodo", "orden" o "ringlera" (chol) del tiempo ( $k$ 'iij). Para una descripción breve y concisa de este tipo de calendarios, véase Sotelo 2012.

26. Tradicionalmente identificado como Erythrina coralloides, en fechas recientes Sotelo y Craveri postularon que se trataría más bien, en el área, de Erythrina berteroana Urb. (2013, p. 187).

27. Véanse Craveri 2012 y Colby y Colby 1986. Sobre el empleo de semillas con fines adivinatorios en el Yucatán colonial consúltese López Cogolludo. 
Entre los diversos datos de interés que contiene el expediente, cabe resaltar lo declarado por un tal Miguel en el sentido de que Pedro Ahcot, uno de los ahcunes de Santiago Atitlán, "se sabe que usa de libro, con cuya lectura, que hace a presencia de los que le consultan, persuade a que de ahí saca lo que dictamina para el efecto; pero es constante que no sabe leer", lo que nos habla del valor que se concedía a la palabra escrita y al conocimiento iconográfico, al tiempo que alerta sobre el uso de técnicas de memorización. De hecho, cabe recordar, en otros procesos, como los encabezados por Margil, se advirtió que entre los especialistas los había ciegos, en especial los "papas" que ocupaban el puesto más alto en la jerarquía, quienes a decir del alcalde mayor español, no obstante su ceguera eran grandes astrólogos y tenían como parte importante de su labor conocer perfectamente los calendarios, cristiano y neopagano; no en balde se examinaba a los alumnos para ver si manejaban con suficiencia los “artes” (Sáenz de Santa María, op. cit., p. 455-456 y 492).

\section{Tiempos de universalidad}

Más allá de peculiaridades y adaptaciones locales, de éstos y otros documentos surge claro que no se trató de un mero intento, más o menos exitoso, de cabalgar calendarios; al mismo tiempo se empleaban sucesos consagrados por la historia occidental para insertar acontecimientos y personajes de raigambre local, "mayanizando", por así decirlo, el devenir occidental o, si se prefiere, universalizando tiempos y espacios mayas al insinuarlos en la cronovisión de los nuevos señores.

Lo anterior se ostenta con claridad meridiana en escritos coloniales que por lo común atribuimos a los mayas, pese a no faltar quienes sospechen de una influencia eclesiástica determinante en su factura (Acuña 1983). Cierto, resulta indudable que el empeño que pusieron los frailes en mantener las lenguas indígenas y escribirlas en el alfabeto latino, con independencia de sus variados motivos, posibilitó a los mayas coloniales plasmar tradiciones -que hasta entonces pertenecían al ámbito de la oralidad-y conocimientos - que, al estar escritos con símbolos no accesibles al profano, eran del dominio exclusivo de las clases dirigentes-; igualmente cierto es que los religiosos contribuyeron en la tarea de hibridar conceptos. Algunos, como Vico en su Theología Indorum, intentaron adecuar a la cosmovisión maya conceptos judeocristianos para mejor trasmitir su mensaje, y crónicas como la de Remesal señalan explícitamente que en Chiapas los dominicos se reunían en las tardes para analizar las "antiguallas" de los indios y estudiar cómo emplearlas para el deseado cambio (Remesal 1966, t. II, p. 749 ss.), mientras que otros, como Landa o Núñez de la Vega, pretendieron explicarse la cosmovisión de sus ovejas a través de su propio bagaje cultural, calificando a menudo aquellas peculiaridades que les 
"Linajes de embustes": cargas de centurias y tiempos universales en el mundo maya colonial

resultaban más chocantes como artilugios ideados desde épocas inmemoriales por el Demonio para confundir a los indios. Y no faltaron quienes aprovechasen tiempos y espacios reprobados y reprobables para ubicar la singularidad ${ }^{28}$.

Pero si bien la impronta cristiana es patente, resulta difícil creer que los eclesiásticos, que buscaban erradicar y sustituir, apostaran por la conjunción de referentes; conjunción que resulta más plausible acreditar a un acto de volición maya, que no sería de extrañar en un pueblo que desde antiguo se caracterizó por su afán conciliador ante otros credos. Más o menos impuesta, en mayor o menor medida deseada, en todo caso lo que resulta de interés es la manera en que los mayas se apropiaron del discurso histórico del otro para insertar el propio; el modo en que, armados con la plasticidad de su cultura milenaria, re-crearon su universo memorioso para encontrar cabida en el nuevo orden que les tocó vivir, y legar a la vez a sus descendientes esa misma posibilidad. Y en su empeño por legitimar su discurso a través del discurso del conquistador, no sólo invocaron tradiciones tenidas por irrefutables, sino que parecen haber aprovechado incluso los balbuceos de los mismos hispanos en su afán por explicarse el origen y naturaleza de los americanos.

En efecto, recordemos, algunos atribuían a cartagineses, coptos, fenicios, romanos y hasta a habitantes de la Atlántida la paternidad de los habitantes del Nuevo Mundo, y abundaban por entonces quienes pretendieran vincularlos con las tribus perdidas de Israel ${ }^{29}$, por lo que no sorprende que en los textos yucatecos aparezcan referencias bíblicas, en particular relativas a la creación $^{30}$, o que el Título de los señores de Totonicapan evoque al primer caudillo y "profeta" Balam Quitzé abriendo con su bastón de mando las aguas del océano para permitir el paso de los pueblos mayas (1980, p. 216) $)^{31}$, y sitúe el surgimiento de las lenguas mayances justo con el estrépito que provocó al derrumbarse la torre de Babel $^{32}$. Esa misma torre con la que el obispo Núñez relacionó a Votán, a más de hacer figurar en su obra al calendárico Imox junto a caldeos y babilonios y asegurar que Ik'alajaw, el venerado señor negro, era de origen etiópico. En una carta de 1692 apuntaba haber obtenido "cuatro

28. Tal hizo por ejemplo fray Manuel Díez, al valerse de un sermón sobre el Infierno para recordar a los tzeltales que era ése el sitio donde vivían sus antiguos dioses, cuyos nombres listó junto con los de diablos bien conocidos por la tradición medieval (apud Ruz 1989).

29. Un valioso y ameno recuento de tales teorías es el realizado por Foa 1987.

30. Como en el "Libro del principio de los itzáes", donde se apunta que Eva, quien naciera "como una gota escurrida de Adán" fue "la primera mujer, la madre de todo el mundo" (ChBCh, p. 91).

31. La Historia quiché de don Juan de Torres, por su parte, señala: "De allá vinieron, del oriente, del otro lado de la laguna, del otro lado del mar, cuando salieron de allá, de la llamada Babilonia" (1957, p. 25).

32. Y encontramos recursos similares en el El Título de Yax, el Título de Pedro Velasco y otras fuentes. 
libros del tepanaguaste [sic], y algunos de ellos en idioma que sólo el Demonio le entiende, y los mismos indios que lo aprenden, y con algunas cláusulas de lengua hebrea..." (Núñez, op. cit., p. 237).

$\mathrm{Si}$, conforme a la visión providencialista que portaban los dominadores, no era posible considerarse parte de la humanidad fuera de la urdimbre cristiana de la historia, ¿por qué no insertar en ésta los hilos de la trama maya? Si la temporalidad hasta entonces conocida había sufrido de una fractura irreparable, ¿por qué no aprovechar las fisuras y ambigüedades de los nuevos marcadores para legitimar tiempos propios? Una vez que la pretendida universalidad del cristianismo les abrió la puerta, los mayas franquearon con paso firme el umbral, adaptando las tradiciones judeocristianas a su realidad mesoamericana, para mejor anclar nuevas raíces.

Y mientras más profundo calasen las raíces, mejor. No es extraño por tanto que el Título de Pedro Velasco, al esbozar los orígenes de los Tamub se remonte hasta el Paraíso terrenal -allí donde se comió "el zapote prohibido"-, o nos hable de la llegada a Babilonia, donde "las parcialidades" convivían "con la gente mexicana y los sacrificadores" y desde donde salieron al pueblo de "Tulán Siwán, siete cuevas y siete barrancas" (1989, p. 173-175) ${ }^{33}$. Como he señalado en algún trabajo previo, la Historia de los Xpantzay de Tecpan, escrita poco después de la conquista, se antoja el compendio más original y sorprendente de tal amalgama. En sus dos primeras páginas vemos conjugarse elementos nahuas, españoles, mayas y hebreos:

Nosotros los principales, éste es nuestro título, cómo vinieron nuestros abuelos y padres cuando vinieron en la noche, en la oscuridad. Somos los nietos de los abuelos Abraham, Isaac y Jacob, que así se llamaban. Somos, además, los de Israel. Nuestros abuelos y padres quedaron en Canaán... Nosotros también estuvimos en Babilonia, donde hicieron una gran casa, un gran edificio todos los hombres. La cima del edificio creció hasta la mitad del Cielo por obra de todos los hombres. Entonces se hablaba un solo lenguaje por todos los grandes. Luego se separaron en la noche... como eran pecadores, se mudaron las lenguas y se volvieron muy diferentes...

[...] Después se levantaron, llegaron a la orilla del mar y pasaron en siete navíos como los de los españoles. Desembarcaron y descansaron allá las siete tribus de los señores: el Ahpozotzil, Ahpoxahil, Ahpotucuché, Ahpoxohinay, Ahtziquinahay, Xpantzay Noh, Ahau Hulahuh Balam.

Luego se levantaron de la orilla del mar; la mitad caminó por el cielo y la otra mitad andando por la tierra, porque eran grandes brujos y encantadores... llegaron al amanecer a Tub Abah y tocaron el tun (1957, p. 121-123).

Los escribas mayas no parecen haber encontrado, pues, mayor dificultad en montarse a ese tren de la historia a donde los empujó la concepción del pasado

33. En su edición de El Título de Totonicapan Carmack y Mondloch sugieren que identificar Tulán con el Paraíso fue idea de los misioneros (1983, p. 212, nota 65). 
"Linajes de embustes": cargas de centurias y tiempos universales en el mundo maya colonial

que esgrimían otros, pero, eso sí, no aceptaron hacer el trayecto en el vagón de segunda al que pretendían confinarlos. En forma clara asientan que formaban parte de "los grandes", y de manera reiterada escriben que sus pueblos descienden de Adán, Jacob, Isaac, Abraham, Moisés... la parte más pura y noble de la tradición hebrea. No reivindican descender de Caín, Cam, Ninus o Indo, como harían algunos cronistas y misioneros, al asimilarlos, junto con el resto de los mesoamericanos, a la porción "maldita" del linaje de Israel ${ }^{34}$.

De hecho, si leemos con cuidado, parecería que desde la perspectiva maya la maldición no provendría de la divinidad sino precisamente de la llegada de los españoles. Por ello, al tiempo que se buscaron en las concepciones llegadas de ultramar nuevos asideros para enraizar su temporalidad y asegurar así su continuidad, las narraciones no dudaron siquiera en alterar la memoria histórica, entre otras cosas idealizando el pasado al presentarlo como una época no sólo caracterizada por la sabiduría y observancia moral, sino libre incluso de enfermedades y tributo (algo que bien podrían haber cuestionado macehuales y esclavos) mientras que la llegada del cristianismo marcó el inicio del sufrimiento (véase, como ejemplo, $C h B C h$, p. 58).

Varios de los pueblos mayas guatemaltecos, como los kaqchikeles autores de El Título de Totonicapan, se reclamaron descendientes de los hebreos: "nosotros los hebreos vinimos con grandes sufrimientos", "nosotros, las hijas y los hijos de los israelitas, de los cananeos; nosotros los hebreos. Así fue nuestra venida de la salida del sol", "Tenían tres nombres: israelitas, cananeos y hebreos se les llamaba a nuestros abuelos y padres" (1983, p. 172-174), mientras que los yucatecos optaron por una asociación particularmente curiosa, al hacer suya la persecución sufrida por el pueblo elegido. Muestra de ello es el pasaje del Chilam que figura como epígrafe de este ensayo. Y otra clara referencia a cómo la antigua forma memoriosa había sido tragada por esa Luna teñida en sangre con la que se asoció al cristianismo ${ }^{35}$, es lo que consigna la Crónica de Chac Xulub Chen: "se terminó de llevar el katún; a saber, se terminó de poner en pie la piedra pública, que por cada veinte tunes (años) que venían se ponía en pie... antes de que llegaran los señores extranjeros, los españoles, aquí a la comarca. Desde que vinieron los españoles fue que no se hizo nunca más" (1987, p. 176177). Cesó, pues, la erección de esas "piedras cuadradas" como califican los

34. Para el caso de los mayas de Chiapas consúltense Núñez, op. cit., p. 111, 132, 274 ss., y Ordóñez 1907. El primero aseguraría que Cam era antecesor legendario de los nativos americanos, a quienes enseñó las supersticiones, y llega a mencionar incluso al Nuevo Mundo como la cuna probable del futuro Anticristo.

35. Sangre que al llegar el cristianismo, asentó el Chilam de Tizimín, bajaría hasta "por los árboles y las piedras", al tiempo que ardían "los cielos y la tierra por la palabra de Dios Padre, del Dios Hijo y del Dios Espíritu Santo" (Libro de los libros..., Segunda rueda profética, p. 84). 
diccionarios a los amay tun, y sus "pedestales", oc tun o chek oc katún ${ }^{36}$. ¿Qué objeto tendría conmemorar modalidades de tiempos para siempre concluidas? Si, como apuntó el chilam de Chumayel, "Once Ahau se llama el katún en que cesaron de nombrarse mayas. Mayas cristianos se nombraron todos" ( $C h B C h$, p. 139), era momento de empeñarse en construir otras formas memoriosas, lo suficientemente plásticas para resignificar el ayer, proyectándolo al mañana.

\section{El "tristísimo" tiempo; las "cargas" de las centurias}

Esta tarea de re-semantización de lo propio resultó sin duda particularmente ardua al tener que realizarse en medio de un cataclismo cultural, que acarreó incluso "la locura" del tiempo, como lo había profetizado el Chilam: "Los que estén sobre el principado de los pueblos, los que tengan medida su cosecha, sabrán que dolorosamente acabará su reinado... Los últimos príncipes, los que estén sobre su loco tiempo y sobre su loca edad, oirán con qué dolor acabará su principado; los que existan en el tiempo en que se extinga el término del katún" (ChBCh, p. 43).

No cabe duda de que para los mayas, como para tantos otros pueblos americanos, el tiempo que instauró el dominio hispano adquirió las dimensiones de una hecatombe, uno de esos "tristísimos" tiempos en los cuales, como señaló el Chilam Balam, el don de la vida sería estrecho y de mísero jugo; tiempos "de infinita amargura", para los hombres mayas, y de espanto y atropello para sus mujeres, asediadas por la lujuria de los españoles ${ }^{37}$.

Las respuestas nativas ante tal catástrofe fueron múltiples a lo ancho del extenso territorio habitado por mayas y a lo largo de los tres siglos que duró la sujeción a España, y podían variar en un mismo pueblo con el transcurrir de los tiempos, o mostrarse incluso diversas en una sola comunidad, conforme a decisiones e intereses grupales y hasta personales ${ }^{38}$. De tan multiforme abanico podemos destacar actitudes iniciales de resistencia que buscaban la erradicación de lo hispano, de las que dan cuenta, entre otros, textos como la Crónica de Chac Xulub Chen ${ }^{39}$, los Papeles de Paxbolón Maldonado ${ }^{40}$, o el famoso

36. Donde "se colocaban los últimos cuatro años, que no entraban en la rueda que pintaban los indios para figurar un Ahau katún, o época de 24 años, sino que los ponían bajo de ella".

37. No se bebería más que granizo y se comerían apenas hojas de chaya (ChBCh, p. 65-66).

38. He tratado este punto con cierto detalle en un trabajo previo (Ruz 2006).

39. En ella $(1987$, p. 169, 173) el señor Nakuk Pech, tras asumir que había llegado el momento de beber "todos hiel a causa de que nos odiaban los santos hombres", declaró que era tiempo de hacer la guerra, y puntualiza: "Yo, por mi nombre, soy Nakuk Pech y no porque entrase el agua [del bautismo] en mi cabeza".

40. Allí se narra cómo, mientras algunos chontales de Itzamcanak asistieron a la destrucción de las imágenes de sus dioses (en Smailus 1975, p. 81-84), otros se internaron en la selva con las deidades de sus antepasados y restauraron su culto (Scholes y Roys 1996, apénd. A). 
"Linajes de embustes": cargas de centurias y tiempos universales en el mundo maya colonial

levantamiento de los Cupules de Valladolid en 1546, cuando se ultimó a los españoles, a los indios que les servían y a los perros y gatos, y se arrancaron de cuajo los "árboles de Castilla" (Relaciones Histórico-Geográficas de la Gobernación de Yucatán 1983, t. 1, p. 67), y, en 1569, el motín protagonizado por los k'iche's de Quetzaltenango ${ }^{41}$.

Tras esos levantamientos, que se revelaron infructuosos, parecería haberse apostado por la conjunción de referentes, como puede observarse en la revuelta de Tekax, Yucatán, en $1610^{42}$, en tanto que en el siguiente siglo hubo apuestas por invertir el orden, como ocurrió en la gran revuelta de la región chiapaneca de Los Zendales de 1712, en la cual los pueblos indios de Cancuc y Huitiupán fueron rebautizados con los nombres de las capitales regionales españolas -Ciudad Real, Guatemala-, mientras que se endilgaba a la primera el topónimo Jerusalén, en tanto que habitada por "judíos". El orden social sería semejante al que estuvo en boga, pero a la inversa: los indios dejarían de pagar tributos y los españoles vendrían a ser sus servidores, al tiempo que sus mujeres pasarían a ser molenderas y mancebas de los naturales. No muy distinto fue lo ocurrido cinco décadas después en el levantamiento de Cisteil, Yucatán, donde se anunciaron la abolición de tributos, el traspaso del poder a manos indígenas (Maní sería la nueva capital), y el perdón de la vida a las españolas "principales" para desposarlas con sacerdotes y capitanes mayas. En uno y otro movimiento se aseguró que quienes murieran en combate resucitarían a los tres días, clara muestra de que hasta los tiempos de la muerte podían ser subvertidos; espejo de lo ocurrido con Cristo.

Para el siglo XIX la carga de la centuria parece haber privilegiado la de la separación, al menos en el caso de los macehualo'ob de Yucatán, quienes tras fracasar en sus intentos por expulsar a criollos y mestizos de la península, pretendieron sobrevivir en el aislamiento de las selvas orientales, al amparo de una Iglesia Maya Cristiana y bajo el cobijo de sus cruces parlantes protegidas por los cuerpos militares de guardias o "compañías". Clamor de utopía teocrática donde lo indio podría al fin disponer de un espacio propio e indisputable, que duró medio siglo antes de ser silenciada, en 1902, por el estruendo de los fusiles y cañones que portaba el Ejército enviado desde México para someter a los rebeldes.

41. Se apedreó al cura, se apaleó a los funcionarios y se asesinó a españoles, declarando "que no se le daba nada del rey ni de la justicia; que no querían que hubiesen ni entrasen españoles en este pueblo" (Zamora Acosta 1986, p. 204-208).

42. Según los españoles, los cabecillas se nombraron papa y obispo, y promovieron la ingestión ritual de balché en copones y cálices, al mismo tiempo que administraban sacramentos, ordenaban sacerdotes y sacaban a las imágenes de sus antiguos dioses en procesión, a la usanza católica. Asimismo, intimaron con un "pregón público” al gobernador indígena Pedro Xiú, aliado de los españoles, y agredieron a los frailes que lo protegían (Porro 1977, p. 65-67). 
Con independencia de que los escritos coloniales den cuenta de la idealización del pasado, del rechazo de un presente de ignominia o de la idealización de un futuro donde el mismísimo Dios cristiano castigaría al español-Anticristo ${ }^{43}$, es claro que todos estos modos de concebir los tiempos -y sus estrategias de rechazo, conjunción, subversión, inversión o separación y aislamiento-constituyeron formas y momentos excepcionales para imaginar cambios que permitieran no únicamente re-crear tradiciones, sino crear nuevas representaciones de su realidad social.

Pueblos al fin y al cabo originalmente agricultores, los mayas parecen haber apostado a la escarda del terreno comunitario y étnico sociohistórico previo, buscando liberarlo de elementos que con el tiempo vinieron a constituirse en maleza o productos innecesarios, para luego sembrarlo con nuevas y antiguas semillas, regarlo y abonarlo, a fin de cosechar identidades una y otra vez reinventadas, como se sigue haciendo, en una labor continua que desborda tiempos y calendarios.

\section{Tiempos mayas, espirales de un ciclo sin fin}

Como cualquier otra creación humana, la mensura de los tiempos, regida por calendarios, ha sabido y sabe de movimientos y cambios. Anclados en las raíces del ayer, pero a la vez dispuestos a la modernidad, no hay tiempos fijos e inmutables, sino constelaciones de cronogramas culturales. Cronogramas, además, que, en el caso de los mayas, como intenté mostrar, no se ciñen a un solo marco, en secuencia y rectilíneo, de acontecimientos y personajes, sino que transcurren por vías diversas, que en ocasiones se acompañan, en otras se traslapan y en algunas más se rozan apenas un momento para, de nuevo, volver a coincidir en algún mañana. $\mathrm{O}$ en algún ayer, porque, a más de tiempos lineales, hay, entre los mayas, tiempos cíclicos, rondando por allí en espirales eternas por intemporales.

Espirales, por cierto, que no se limitan a lo terreno, puesto que también los muertos se incluyen en ellas. ¿Cómo podría ser de otro modo si es bien sabido que los difuntos permanecen cerca, atentos a la suerte de sus familiares? Por algo se les invoca para que se manifiesten (en sueños, visiones o con acontecimientos extraordinarios) cuando hay que vender un terreno, desposar a un miembro del linaje, tomar una decisión trascendente o incluso solucionar

43. Me refiero a la identificación que hace el Chilam Balam de Chumayel de los castellanos con el Anticristo. Tras declarar "Si no hubieran venido los 'hombres de Dios', no habría despojos, no habría codicia ni menosprecio de la sangre de los otros hombres, ni de las fuerzas de los humildes. De sus propias fuerzas comería cada uno", confió en que contra ese Anticristo "chupador del pobre indio", bajaría algún día "la justicia de Dios, de un golpe sobre el mundo" (op. cit., p. 170). 
"Linajes de embustes": cargas de centurias y tiempos universales en el mundo maya colonial

una pugna entre familias, rogándoles intervengan con los parientes difuntos de los querellantes. Al fin y al cabo ellos también se verán beneficiados si los problemas se solucionan antes de que les toque, en otros cuerpos y en otros días, retornar a los espacios terrenales.

Días, horas, espacios... Porque los tiempos, densos de significados, también requieren ocupar espacios. Para algún h-men yucateco contemporáneo, los tiempos ya pasados se ubican del lado derecho y los futuros a la izquierda. Desde allí unos y otros se mueven, ascendiendo a partir de la cintura, hasta llegar a tocarse arriba de la cabeza. Para los tojolabales, el pasado, tiempo ya visto (en tanto que ya vivido), se sitúa frente a los ojos de los hombres, mientras que el futuro, que no se puede ver, se ubica a sus espaldas.

Futuro, espaldas... Sobre las espaldas de sus divinos cargadores, de hecho, se montaban los días por venir, sucediéndose como en un carrusel en fechas dispares: Akbal será el tercer día de un mes, el décimo del otro, el cuarto en el que le sucederá... Chicchán, Kimí, Manik, Lamat, Muluc y todos los demás "dueños" de los días harán otro tanto. A ellos, a sus dueños, habrían de dirigirse los ah kin, "los del tiempo", para invocar una gracia o conjurar un peligro de los que pudieran ocurrir en el periodo en que la existencia humana quedase a su guarda y cuidado, tal como hoy lo siguen estilando los "contadores de los días", sus herederos.

Bajo el dominio hispano hubo que "cabalgar" tales formas de concebir la temporalidad, útiles en el pretérito, con los esquemas aportados por los nuevos señores, en particular con la visión cristiana de la cronología, donde el nacimiento de Cristo era el parteaguas entre el "ahora" y el "antes", y la visión de pasado y futuro se amoldaban a una perspectiva de la historia de tipo "providencialista", regida por los designios de la divina providencia. Los mayas, acostumbrados a lidiar con las veleidades de los tiempos, acomodaron su propio ayer-mítico, histórico y profético- para insertarlo en las novedosas cronologías y espacios aportados por los dominadores: plantaron en el Paraíso cristiano un zapote como árbol de la fruta prohibida, y calificaron tal sitio como abundante en maíces y quetzales; aprovecharon, como vimos, la confusión lingüística que según la tradición hebrea surgió tras la caída de la torre de Babel para ubicar allí el nacimiento de sus idiomas; atribuyeron al bastón de mando del "profeta" Balam Quitzé el haber abierto las aguas del Océano para permitir el paso de los pueblos mayas salidos de siete cuevas, siete barrancas. Y a fin de completar el ciclo, hablaron hasta del Anticristo, "explotador de los indios", al que describieron como español... y continuaron caminando hacia el mañana.

Un mañana con marcaje y lenguajes apropiados para nuevos tiempos, pues si bien en numerosas localidades el antiguo calendario rige aún actividades agrícolas y rituales (mezclado, por cierto con cronometrías julianas y gregorianas en lo que a la veneración de los santos respecta), hay también otros lapsos y 
períodos que norman parte de la cotidianeidad de cerca de siete millones de mayas. Deletreados en una treintena de idiomas propios, a los que se suman otros como el español y el inglés, los cronogramas han de atender por igual los tiempos académicos del estudiante o el profesionista pokomam, tzutuhil o tojolabal, las fluctuaciones del mercado que aquejan al vendedor de flores zinacanteco, o al maya peninsular que se desenvuelve como albañil en Mérida o como prestador de servicios en Cancún.

Tiempos que para su mensura y transmisión exigen otros instrumentos. El comerciante chamula de La Hormiga, en la periferia de San Cristóbal, tiene hoy que acompasar sus plazos de entrega a lo que le signifique el desplazamiento en motocicleta desde su tortillería hasta la casa desde donde se marcó su celular; el estudiante maya yucateco de Valladolid, para concertar encuentros con sus compañeros, verá acortarse tiempos y grafías en la pantalla de su tablet o su $i$-pod; el pastor protestante del centro de Campeche habrá de adecuar la "invocación" en maya que -variante de la antigua petición de lluvias- realiza junto a la bomba eléctrica que surte de agua los campos, aunque ya sin preocuparse por hacerlo en fecha exacta, que al fin y al cabo el motor no sabe de urgencias estacionales; el tzotzil de Chamula continúa depositando sus ofrendas de copal y velas ante la imagen del caballo del apóstol Santiago, pero sin depender ya de los tiempos de destilación del posh, pues lo ha sustituido con Coca Cola; los ch'uleltik-sombra, componentes de la persona tzeltal de Cancuc, siguen vagando por las montañas sagradas, pero en ellas se escuchan ahora los ruidos de televisores, avionetas y celulares...

Las tejedoras de Magdalenas persisten en seguir brocando mitos milenarios en los huipiles ceremoniales, al tiempo que las bordadoras de hipiles de Quintana Roo plasman elementos de la flora y fauna local para atraer con mayor facilidad a compradores potenciales (su contraparte de Campeche, en cambio, privilegiará torreones, anclas y barcos para satisfacer los empeños estatales por diferenciarse, hasta en el atuendo, de sus vecinos yucatecos). La comadrona chuj da instrucciones por su celular mientras se apresura por llegar a la vivienda donde la parturienta espera. Del otro lado de la frontera, la anciana partera tojolabal, respetuosa de la tradición, atiende calmadamente a que el recién nacido, saliendo de la madre en cuclillas, se dé tiempo para tocar a la Santa Madre Tierra antes que nada.

Distintos tiempos para conjurar, procurar o atender afanes de siempre y nuevas batallas. Un contador de los días de Totonicapán consulta su calendario e interroga a las almas de los antepasados a fin de elegir la fecha más propicia para celebrar el matrimonio de uno de sus descendientes, mientras que los herederos de los macehualo'ob seguidores de la yax cruz -la cruz-ceiba cuyos discursos alentaron a los combatientes en la guerra de Castas-, saben que para ellos no hay fechas especiales; día tras día deberán librar la batalla para mantener su 
"Linajes de embustes": cargas de centurias y tiempos universales en el mundo maya colonial

santuario en medio de un Tulum atestado de jóvenes turistas estadounidenses spring breakers, y donde la avidez de las inmobiliarias provocó que los dirigentes acordaran sembrar una hectárea de maíz en común, a fin de evitar, al menos simbólicamente, perder los nexos con el sagrado grano, materia con que los dioses crearon a los hombres. Pocos, empero, acostumbran ya poner en las manos de los pequeños utensilios de labranza cuando se realiza la ceremonia del hetzmek, tendiente a facilitar, prefigurándolo, el futuro desempeño laboral. ¿Qué objeto tendría si ya ni hay tierra donde hacer milpa hay? Por algo los padrinos llevan ahora pequeños diccionarios de inglés y hasta minúsculas computadoras de plástico, sin duda más útiles para presagiar un porvenir exitoso como prestadores de servicios en la Riviera Maya.

Ni siquiera espíritus y divinidades escapan a la mudanza de temporalidades y eternidades. Así, el narrador tzotzil de mitos actualiza los cronómetros divinos para que Jesús descienda de un avión a entregar el maíz a los hombres, y en otro avión, más comercial, más tangible, con boleto pagado por un comité binacional, el especialista kanjobal viaja hasta el sitio donde se registró la muerte violenta de un emigrante laboral, a traer consigo de regreso al espíritu que va a "levantar" en el lugar mismo del deceso, para evitar que quede encadenado a un paisaje particularmente inhóspito por foráneo.

Nuevas confluencias, en fin, de calendarios para vivos y difuntos. El balbastix ixil de Nebaj, hincado frente a la mesa-altar donde se depositó el bulto mortuorio, lee uno por uno los nombres que contiene la lista de familiares que precedieron en su viaje al occiso, suplicándoles vengan a acompañarle a sus nuevos espacios y temporalidades. Y mientras él recurre a esa atesorada herencia memoriosa, a cientos de kilómetros de distancia, el huaxteco acelera el rezo de rosarios en beneficio de su familiar, también hace poco difunto, que en vida anduvo "lejos, por [muchos] caminos", para que, "mientras recoge sus pasos", no vaya a perderse en los laberintos de la desmemoria. A su vez, el kanjobal de Santa Eulalia acude al panteón a los nueve días de un deceso a "llamar al pixan" para que lo siga a rezar a la iglesia y luego a comer a la casa. Ya desharán al día siguiente el camino, y se regará arena alrededor de la tumba, con lo que quedará claro al muerto que su existencia no se rige ya por los mismos calendarios. No en balde el kaqchikel de Santa Cruz la Laguna espera que llegue el día Kimé para pedir un favor a los antepasados difuntos, aprovechando que, como cualquiera sabe, es por entonces cuando éstos deambulan por los caminos, desde el amanecer hasta el ocaso. La madre muerta de un pequeño niño yucateco de Dzoyaxché, en cambio, tendrá que esperar la oscuridad de la noche para ir a lavar la ropa del huérfano que el viudo descuida...

¿Alguien podría extrañarse de tales cambios, conjunción y modernidad de signos en una cultura fascinada desde siempre por la mudanza de los tiempos? ¿Alguien se atrevería a poner en duda la extraordinaria capacidad de los mayas 
para urdir futuro y pasado en una trama memoriosa y profética que da cuenta de la vigencia de su cultura, nunca la misma, siempre única, porfiadamente actual?

Cierto, a nadie escapa que en la actualidad se ha restringido el empleo de los calendarios antiguos como instrumentos privilegiados de gobierno y poder (en tanto expresión de conocimiento esotérico del tiempo y su control), variando el uso de la cronología como recurso político, pues es igualmente cierto que en muchos sentidos son ahora otros los lapsos y períodos (por no hablar de categorizaciones, metáforas y figuras) que norman buena parte de la cotidianeidad de los mayas. Pero, sea como fuere, perdura la cronometría de tiempos que, desde siempre, preocupan a los comunes: el de las predicciones para el futuro de los pequeños, el de la regulación de los rituales agropecuarios, el de las posibilidades de emplear lapsos temporales para conjurar la aleatoriedad del mal o convocar la llegada de un don..., asuntos a menudo de especialistas, que bien pueden recurrir a los calendarios como tecnología utilitaria, lo cual no invalida sus características de creación mental o de categoría sociogramatical, como se hace obvio al revisar cualquier diccionario, pero en particular los coloniales, que hacen expreso cómo se diferenciaban tiempos ordinarios y extraordinarios, fastos o infaustos, conforme a cuyos pronósticos se regirían acontecimientos de naturaleza social, ritual y hasta onírica. Tiempos, sueños, mitos, olvidos, memoria, historia...

\section{Consideración final}

Los ejemplos expuestos, y muchos otros rasgos que me ha sido imposible siquiera evocar, nos alertan sobre los riesgos que enfrenta quien pretenda aplicar mecánicamente cronovisiones, cronometrías y cronotopos de linaje occidental al devenir maya, sin tomar en cuenta criterios tales como la secuencialidad de los acontecimientos, la insistencia maya en conjuntar los hechos dependiendo de su sincronía más que de la diacronía que según nosotros les da origen, y el hecho de que la enunciación del suceso puede variar dependiendo del emisor, el receptor, y el contexto mismo de enunciación.

Asunto de particular interés, nos recuerda Manuel Gutiérrez (2003, p. 14-15), es que Occidente hablará de historia cuando se trata de concepciones lineales, donde un acontecimiento singular -irrepetible- puede servir de marcador, mientras que podrá tachar de "profecía" a aquello que en una concepción cíclica o secuencial se muestra como "algo previsto [y] repetido periódicamente". "Profecías" que, en el caso maya no se atienen a una perspectiva exclusivamente religiosa, sino que, a más de someterse a una "espacio-temporalidad" distinta, pueden estar cargadas de una clara intencionalidad política, posibilitando (y de hecho urgiendo) re-lecturas sucesivas de un mismo acontecimiento, una y otra vez re-significado, como puede verse desde los textos prehispánicos hasta los discursos contemporáneos. Inacabable re-interpretación a la luz de códigos 
"Linajes de embustes": cargas de centurias y tiempos universales en el mundo maya colonial

culturales únicos y singulares, que poseen esquemas semánticos propios, en tanto se anclan en tiempos y espacios que no son necesariamente los nuestros ni se simbolizan de idéntica manera, ya que el sentido que se les atribuye discrepa con frecuencia del que nosotros podemos asignarles ${ }^{44}$.

A más de validar estos supuestos, los textos nos muestran las variantes cronológicas y regionales que caracterizaron la interacción entre los pueblos mayas y sus nuevos señores, y en especial la peculiar relación que se dio con las concepciones temporales y religiosas que éstos portaban, tanto a nivel de creencias como de prácticas. En este sentido, se antoja de particular relevancia analizar la impronta tan distinta que, en lo que a patrones de transculturación toca, imprimió el actuar de las órdenes a cargo de la evangelización en diversos territorios. Así, varios de los postulados que desprenden de la enérgica acción franciscana en Yucatán estudios tan acuciosos como los de Hanks (op. cit.) o Farriss (1984) o Solís (2005), contrastan seriamente con el tímido, cuando no desdeñoso, actuar de los doctrineros mercedarios en los Altos Cuchumatanes (León 2004), área que no en balde sigue siendo uno de los bastiones de antiguas maneras mayas de concebir y vivir el tiempo.

A la par de la influencia de mendicantes y clérigos, es obvio que habrá de aquilatarse la volición maya por acceder o no a tal o cual patrón de cambio cultural (cronovisiones incluidas) y, más aún, atender a las distintas vías por las que optaron para hacerlo, pues a la luz de las divergencias registradas resulta imposible apostar por "una" sola respuesta maya ante las actitudes hispanas (que, dicho sea de paso, también cambiaron en tiempos y espacios). Los documentos dan clara cuenta de que las respuestas fueron diversas y los actores implicados en ellas variaron, si bien no deja de ser interesante constatar el papel primario que a menudo jugaron tanto autoridades tenidas por "tradicionales" como otras asociadas con las distintas esferas del poder hispano, incluyendo el eclesiástico. Catequistas y caciques figuran a menudo, por ejemplo, entre los acusados de actitudes supersticiosas y hasta subversivas.

Sea como fuere, surgidas de una manera propia de entender el mundo y representarse su devenir, no es extraño que las concepciones mayas sobre la temporalidad difieran a menudo de las nuestras. Y lo hacen desde la forma de pensar el origen del tiempo; un tiempo concebido como predecesor incluso de la creación, que "empezó a caminar por sí mismo", que nació antes que el cielo, el mar y la tierra, la escalera del agua, los árboles y las piedras (Sodi 1961, passim) ${ }^{45}$; un tiempo

44. "El que un mismo acontecimiento pueda ofrecer a la perspectiva maya diversos significados no lleva implícito un desorden interpretativo; se trata más bien de estrategias diferentes de construcción de identidad (por el recuerdo o por el olvido), dependiendo de lo que esté en juego memorar; testimonio de un proceso permanente de reconfiguración que articula distintos registros (autóctonos o alóctonos; fonéticos, gestuales, tejidos o escritos)" (Ruz 2006).

45. Para su traducción al castellano, Sodi empleó la versión paleográfica maya de Roys (1993). 
que transcurre por espacios diversos y múltiples, haciéndolo en ocasiones de manera simultánea, y que a veces no es posible conquistar sino con armas tan singulares como la reverencia, la ofrenda o la sumisión debidas a lo inefable. Al fin y al cabo, desde la cosmovisión maya, en el principio fue el tiempo, y el tiempo era dios.*

* Manuscrit reçu en avril 2015, accepté pour publication en juin 2015.

Este artículo forma parte del número especial Compases y texturas del tiempo entre los mayas: lo dicho, lo escrito, lo vivido.

\section{Referencias citadas}

AcuÑa René

1983 "El Popol Vuh, Vico y la Theologia Indorum", in Robert Carmack y Francisco Morales (eds), Nuevas perspectivas sobre el Popol Vuh, Editorial Piedra Santa, Guatemala, p. 1-16.

Álvarez María Cristina

1980-84 Diccionario etnolingüistico del idioma maya yucateco colonial, UNAM, IIFL, CEM, México, 2 vols.

Bricker Victoria R. y Helga-María Miram

2002 An Encounter of Two Worlds. The Book of Chilam Balam of Kaua, Middle American Research Institute, New Orleans.

CASo BARrera Laura (ed.)

2011 El Chilam Balam de Ixil. Facsimilar y estudio de un libro maya inédito, Artes de México e INAH, México.

Campbell Lylle

1981 "El pasado lingüístico del sureste de Chiapas", Investigaciones recientes en el área maya, tomo 1, Sociedad Mexicana de Antropología, San Cristóbal de Las Casas, p. 165-184.

Colby Benjamin y Lore Colby

1986 El contador de los días. Vida y discurso de un adivino ixil, Fondo de Cultura Económica, México.

Cото Thomas de

1983 Thesaurus verborum. Vocabulario de la lengua cakchiquel vel guatemalteca, nuevamente hecho y recopilado con summo estudio, travajo y erudición. Edición, introducción y notas de René Acuña, UNAM, México.

Craveri Michela

2010 "Adivinación y pronóstico entre los mayas actuales", Arqueología Mexicana, XVII (103), p. 64-69.

2012 "Magia del tiempo y adivinación en las Tierras Altas de Guatemala", in El Arte maya del tiempo/ The Art of Maya Timekeeping (edición bilingüe español-inglés), Artes de México, 107, Editorial Artes de México, México, p. 61-65. 
"Linajes de embustes": cargas de centurias y tiempos universales en el mundo maya colonial

Crónica de Chac-Xulub-Chen

1987 in Agustín Yáñez (ed.), trad. de H. Pérez Crónicas de la conquista, UNAM, México.

Crónicas indígenas de Guatemala

1957 Traducción y notas de Adrián Recinos, Editorial Universitaria, Guatemala.

CHAClán José (transcripción)

1989 "Curanderos adivinos en la jurisdicción de Sololà", in Boletín del Archivo Histórico del Arzobispado de Guatemala, vol. 1 (3), p. 122-132.

El libro de los libros de Chilam Balam

1974 Traducción de Alfredo Barrera Vázquez y Silvia Rendón, Fondo de Cultura Económica, México.

El Título de Totonicapán

1983 Traducción y edición de Robert Carmack y James Mondloch, UNAM, IIFL, CEM, México.

El Título de Yax y otros documentos quichés de Totonicapán

1989 Traducción y edición de Robert Carmack y James Mondloch, UNAM, IIFL, CEM, México.

FARRISS Nancy M.

1984 Maya Society under Colonial Rule. The Collective Enterprise of Survival, Princeton University Press, Princeton.

FoA Anna

1987 "Il popolo nascosto. Il mito delle tribù perdute d'Israele tra messianesimo ebraico ed apocalissi cristiana (XVI-XVII secolo)", in Itinerari ebraico-cristiani. Società, cultura, mito, Schena Editore, Fasano, p. 129-160.

Granado BAeza Bartolomé José del

1946 Informe sobre las costumbres de los indios de Yucatán, Vargas Rea, México. GutiérRez Estévez Manuel

2003 "El estilo de la civilización amerindia", Revista de Occidente, 269, Fundación José Ortega y Gasset, Madrid, p. 7-24.

HANKS William F.

2010 Converting Words. Maya in the Age of the Cross, University of California Press, Berkeley.

HiLl Robert M.

2001 Los kaqchikeles de la época colonial: Adaptaciones de los mayas del altiplano al gobierno español, 1600-1700, Plumsock Mesoamerican Studies y Cholsamaj, Guatemala.

Historia de los Xpantzay de Tecpan Guatemala

1957 in Crónicas indígenas de Guatemala, Traducción y notas de Adrián Recinos, Editorial Universitaria, Guatemala, p. 120-129.

Historia quiché de don Juan de Torres

1957 in Crónicas indígenas de Guatemala, Traducción y notas de Adrián Recinos, Editorial Universitaria, Guatemala, p. 25-67.

LANDA Diego de

1978 Relación de las cosas de Yucatán, Editorial Porrúa, $11^{a}$ edición, México. 
Mario Humberto RuZ

León CÁzAres María del Carmen

2004 Reforma o extinción. Un siglo de adaptaciones de la Orden de Nuestra Señora de la Merced en Nueva España, UNAM, IIFL, IIH, México.

Libro de Chilam Balam de Chumayel

1973 Traducción de Antonio Mediz Bolio, UNAM, México.

López Cogolludo Diego

1954 Historia de Yucatán, prólogo de José Ignacio Rubio Mañé, Academia Literaria, México.

Manuscrito de Chan Cah

1982 Grupo Dzibil, CEID, México.

Memorial de Sololá o Anales de los cakchiqueles y Título de los señores de Totonicapan

1980 Traducción, introducción y notas de Adrián Recinos, Fondo de Cultura Económica, México.

Moliner María

1988 Diccionario de uso del español, Gredos, Madrid, 2 vols.

NúÑEZ DE LA VEGA Francisco

1989 Constituciones diocesanas del obispado de Chiapa, María del Carmen León y Mario Humberto Ruz (eds), UNAM, IIFL, CEM, México.

OrdóÑEZ Y AguiAR Ramón de

1907 Historia de la creación del cielo y de la tierra conforme al sistema de la gentilidad americana. Theología de los Culebras, figurada en ingeniosos gerogliphicos, symbolos, emblemas y metaphoras, Diluvio universal, dispersión de las gentes, verdadero origen de los indios: su salida de Chaldea, su transmigración a estas partes Septentrionales, transito por el Océano y derrota que siguieron hasta llegar al Seno Mexicano..., s.e., México.

Porro Antonio

1977 O messianismo maya no periôdo colonial, tesis doctoral en Antropología Social, Universidad de Sâo Paulo, Sâo Paulo.

Relaciones Histórico-Geográficas de la Gobernación de Yucatán

1983 Mercedes de la Garza et al. (eds), Paleografía de María del Carmen León, UNAM, IIFL, CEM, México.

Remesal Antonio de

1966 [3 $3^{\text {a }}$ ed.] Historia general de las Indias Occidentales y particular de la Gobernación de Chiapa y Guatemala, Prólogo de Antonio Batres, Editorial José de Pineda Ibarra, Guatemala, 4 vols.

RoDAz Juan de

1989 Arte de lengua tzotzlem o tzinacanteca, con explicación del año solar y un traslado de las quentas de los indios (1723), in Mario Humberto Ruz (ed.), Las lenguas del Chiapas colonial, vol. 1, UNAM, IIFL, CEM, México.

Ruz Mario Humberto

1989 Las lenguas del Chiapas colonial. Manuscritos de la Biblioteca Nacional de París. vol. 1: lenguas mayanses (tojolab'al, cabil, mochó, tzotzil y tzeltal). (Versión paleográfica, introducción y notas de Mario Humberto Ruz), UNAM, IIFL, CEM, México. 
"Linajes de embustes": cargas de centurias y tiempos universales en el mundo maya colonial

1997 Gestos cotidianos. Acercamientos etnológicos a los mayas de la época colonial, Instituto de Cultura de Campeche, Universidad Autónoma de Campeche, Universidad Autónoma del Carmen e Instituto Campechano, Campeche.

1999 La Iglesia en el área maya. Documentos en tres archivos romanos, UNAM, IIFL, CEM, México.

2003 "Cada uno con su costumbra. Memoria y olvido en los cultos funerarios contemporáneos", in Andrés Ciudad, Mario Humberto Ruz y Josefa Iglesias (eds), Antropología de la eternidad. La muerte en la cultura maya, Sociedad Española de Estudios Mayas, UNAM, IIFL, CEM, Madrid, p. 531-548.

2006 "Gestos, voces y letras de resistencia maya colonial", in Rosa Maria Grillo (ed.), L'America Latina tra civiltà e barbarie, Universidad de Salerno y Oèdipus, Salerno, Italia, p. 337-376.

2010 "La memoria maya: colección de olvidos", in Mario Humberto Ruz y Adam T. Sellen (eds), Las vitrinas de la memoria, los entresijos del olvido. Coleccionismo e invención de la memoria cultural, UNAM, CEPHCIS, México, p. 165-188.

[en preparación] En las orillas del mundo. Religión y heterodoxia en la Guatemala colonial.

Ruz Mario Humberto et al.

2002 Memoria eclesial guatemalteca. Las visitas pastorales, vol. 1, UNAM, CONACyT y Arzobispado de Guatemala, (Siglo XVII), México.

SÁEnz de SAnta María Carmelo

1981 "Una visión etnorreligiosa de la Guatemala de 1704, según fray Antonio Margil de Jesús", Revista de Indias, 165-166, p. 445-497.

SÁnchez del Aguilar Pedro

1987 Informe contra Idolorum cultores del obispado de Yucatán, año 1639, in El alma encantada. Ed. facsimilar de Anales del Museo Nacional, tomo 6 [1892], Fondo de Cultura Económica e INI, México, p. 23-122.

Scholes France V. y Ralph L. Roys

1996 Los chontales de Acalan Tixchel, Traducción de Mario Humberto Ruz y Rosario Vega, UNAM, IIFL, CEM y CIESAS, México.

Smailus Ortwin

1975 El maya chontal de Acalán. Análisis lingüistico de un documento de los años 1610-1612, UNAM, IIFL, CEM, México.

Sodi Morales Demetrio

1961 “Como nació el Uinal”, Estudios de Cultura Maya, I, p. 211-219.

Solís RoBleda Gabriela

2005 Entre la tierra y el cielo. Religión y sociedad en los pueblos mayas del Yucatán colonial, CIESAS, Miguel Ángel Porrúa e Instituto de Cultura de Yucatán, México.

Sotelo SANTos Laura Elena

2012 "El arte de medir el tiempo", in El Arte maya del tiempo / The Art of Maya Timekeeping (edición bilingüe español-inglés), Artes de México, 107, Editorial Artes de México. México, p. 14-17. 
Mario Humberto RuZ

Sotelo Santos Laura Elena y Michela Craveri

2013 "La adivinación y las semillas: modelos míticos en el universo k’iche",, in Mercedes de la Garza y María del Carmen Valverde Valdés (eds), Continuidades, cambios y rupturas en la religión maya, UNAM, IIFL, CEM, México, p. 169-214.

The Book of Chilam Balam of Chumayel

1933 Ralph L. Roys (ed. and translation), Carnegie Institution, Washington.

The Book of Chilam Balam of $\mathrm{Na}$

2000 Ruth Gubler and David Bolles (Translation, and Edited Text), Labyrinthos, Lancaster (CA).

Título de Pedro Velasco

1989 in El Título de Yax y otros documentos quichés. Traducción y edición de Robert Carmack y James Mondloch, UNAM, IIFL, CEM, México, p. 139-192.

Velásquez García Erik

2010 "El antiguo futuro del k'atun. Historia y profecía en un espacio circular", Arqueología Mexicana, XVII (103), p. 58-63.

ZAMORA Acosta Elías

1986 "Resistencia maya a la colonización: levantamientos indígenas en Guatemala durante el siglo XvI", in Miguel Rivera y Andrés Ciudad (eds), Los mayas de los tiempos tardíos, Sociedad Española de Estudios Mayas, Madrid, p. 197-214. 